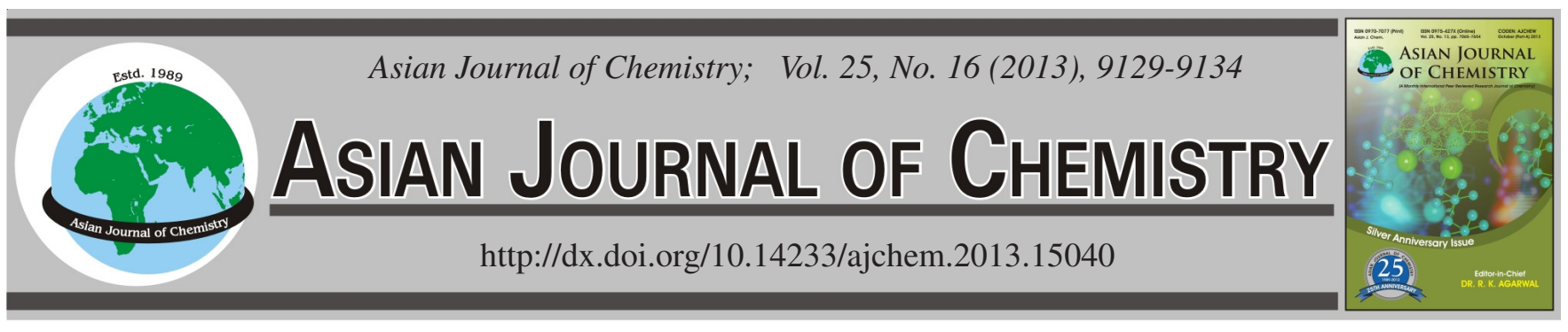

\title{
Adsorption Removal of Phosphorus from Aqueous Solution by Heat-Activated Alum Sludge
}

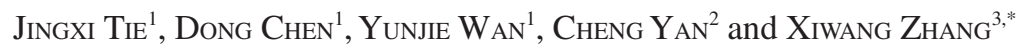

${ }^{1}$ School of Environmental and Municipal Engineering, North China University of Water Resources and Electric Power, Zhengzhou 450011, P.R. China

${ }^{2}$ Department of Environmental Science and Engineering, Fudan University, Shanghai 200433, P.R. China

${ }^{3}$ School of Applied Sciences and Engineering, Monash University, Gippsland Campus, Churchill Vic 3842, Australia

*Corresponding author: Fax: +61 3 51226449; Tel: +61 3 51226453; E-mail: xiwang.zhang@monash.edu.au; tjx@ncwu.edu.cn

\begin{abstract}
Eutrophication caused by phosphorus is one of the major water pollution problems. In this study, the waste material, alum sludge, was utilized as a phosphorus adsorbent. A facile method of thermal treatment was developed to improve the adsorption capacity of alum sludge. The prepared alum sludge adsorbent was characterized by XRD, XRF and FTIR techniques to analyze its crystal phases and surface properties. The heat treatment had significant impact on the physico-chemical properties of the alum sludge adsorbent, which further influenced its adsorption performance. The optimal heat treatment was $300{ }^{\circ} \mathrm{C}$. The phosphorus adsorption onto the alum sludge sorbent fitted to Freundlich isotherm very well and the adsorption kinetics followed the pseudo-second-order rate equation. The solution temperature and $\mathrm{pH}$ both had apparent influence on alum sludge adsorption capacity. Higher solution temperature and lower $\mathrm{pH}$ were favorable for phosphorus adsorption. Thermodynamic parameters showed that the phosphorus adsorption onto alum sludge was spontaneous and endothermic.
\end{abstract}

Key Words: Alum sludge, Phosphorus, Heat treatment, Adsorption.

\section{INTRODUCTION}

Eutrophication is recognized as a water pollution problem around the world. It poses a problem not only to ecosystem, but to humans as well. Phosphorus is considered as one of the key nutrients to cause eutrophication ${ }^{1}$. At the same time, phosphorus is a nonrenewable resource that will be depleted in the next few decades ${ }^{2}$. So, it is of great importance to remove and recover phosphorus from wastewater. Many techniques such as adsorption, chemical precipitation and aerobicanaerobic-anoxic processes have been used for removal of phosphorus from the wastewater ${ }^{3-5}$. Among these techniques, adsorption has drawn more attention due to its high efficiency and easy maintenance and the technique can be more attractive if low cost and high efficient adsorbent is used.

In recent years, many efforts have been put on the feasibility studies using waste materials as phosphorus adsorbent such as red mud ${ }^{6-10}$, fly ash ${ }^{10-12}$, slag ${ }^{13}$, orange waste ${ }^{14}$. Therefore, converting waste materials into phosphorus adsorbents is an eco-friendly technique for both their disposal and phosphorus removal. Alum sludge (AS) is a by-product generated from the coagulation/sedimentation process in drinking water treatment plants where polyaluminium is used as coagulant. A large amount of alum sludge is produced in drinking water treatment plants every day in China and discharged into the environment directly without any treatment due to the $\cos \mathrm{t}^{15}$.

It has been proved that alum sludge was an efficient adsorbent for phosphorus removal because it contains high content of alum ${ }^{16,17}$. However, most research carried out in this field has focused on the investigation of alum sludge adsorption properties. Comparatively, little work has been done on how to improve the alum sludge adsorption capacity of phosphorus. In this study, a facile method of heat treatment was developed to improve its adsorption capacity. The influence of calcination temperature on the alum sludge physicochemical properties and its adsorption capacity was investigated. The adsorption kinetics and isotherm were measured.

\section{EXPERIMENTAL}

Preparation of adsorbent: The alum sludge used in this study was taken from the sludge pool in Sino-French water supply Co, Ltd., Zhengzhou, Henan, P.R. China. The colleted alum sludge was air-dried for a week at room temperature and then was crushed and sieved with an 80 mesh sieve. The sieved alum sludge powder was further treated thermally at the temperature ranging from $100-800{ }^{\circ} \mathrm{C}$, progressively increased by $100{ }^{\circ} \mathrm{C}$. Finally, the alum sludge was cooled down to room temperature naturally and was stored in plastic bags for use. 
Adsorbent characterization: The specific surface areas of the prepared alum sludge adsorbents were determined by the BET method with $\mathrm{N}_{2}$ gas on a high speed automated surface area and pore size analyzer (Model NOVA400e, Quantachrome Corporation, USA). The chemical compositions were analyzed on an X-ray fluorescence spectrometer (XRF, Model ARL9800, Thermo Electron Co., Switzerland). The crystal structures of the adsorbents were characterized on a powder X-ray diffraction (XRD, Model X'TRA, Thermo Electron Co., Switzerland). The functional groups on adsorbents were determined using a Fourier Transform Infrared Spectroscopy (FTIR, Model nexus870, Thermo Nicolet Corporation, USA).

Phosphorus removal studies: The phosphorus solutions used in this study were prepared by dissolving a certain amount of $\mathrm{KH}_{2} \mathrm{PO}_{4}$ into distilled water. The initial $\mathrm{pH}$ of phosphorus solution was adjusted to the predetermined value with $0.1 \mathrm{M}$ $\mathrm{KOH}$ or $\mathrm{HCl}$ solution. The $\mathrm{pH}$ of the solutions was measured using a pH meter (pHS-3C, Leici Ltd., China). All the reagents used in this study were of analytical grade. The batch phosphorus adsorption experiments were carried out in $100 \mathrm{~mL}$ conical flasks with stopper. These flasks were shaken on a horizontal shaker at a speed of $120 \mathrm{rpm}$. After adsorption, the solution was filtrated through a $0.45 \mu \mathrm{m}$ membrane and the phosphorus concentration in the filtrate was measured by the ascorbic acid method ${ }^{18}$. The removal capacity of phosphorus of the alum sludge was calculated by the following equation:

$$
\mathrm{q}=\frac{\left(\mathrm{C}_{0}-\mathrm{C}_{\mathrm{e}}\right) \mathrm{V}}{\mathrm{m}} \%
$$

where $\mathrm{q}$ is the amount of phosphorus adsorbed by per unit mass of alum sludge $(\mathrm{mg} / \mathrm{g}), \mathrm{C}_{0}$ and $\mathrm{C}_{\mathrm{e}}$ are the initial and final concentrations of phosphorus in solution $(\mathrm{mg} / \mathrm{L})$, respectively; $\mathrm{V}$ is the volume of the solution $(\mathrm{L})$ and $\mathrm{m}$ is the weight of alum sludge $(\mathrm{g})$.

\section{RESULTS AND DISCUSSION}

Characterizations of adsorbents: The chemical compositions and BET surface areas of the alum sludge treated at $100{ }^{\circ} \mathrm{C}$ (AS100), $300{ }^{\circ} \mathrm{C}$ (AS300), $800{ }^{\circ} \mathrm{C}$ (AS800) are shown in Table-1. It can be seen that silicon was the dominant component in the three samples, which is the main component of the clay particle in the raw water. The silicon precipitated with the hydrolyzates of poly aluminum chloride (PAC) after poly aluminum chloride was added in coagulation unit. The second largest content component was Al based chemicals, which were mainly from the hydrolyzates of poly aluminum chloride. The specific surface areas of the three materials were different and the AS300 had the largest specific surface area. The possible reason is that water was expulsed from the alum sludge to create more porosity to enlarge the specific surface area. In contrast, AS800 had the smallest specific surface area. It might be attributed to the fact that some hydroxyl groups were decomposed and the sintering shrinkage of alum sludge occurred at $800{ }^{\circ} \mathrm{C}^{6}$.

The XRD patterns of the AS100, AS300 and AS800 are shown in Fig. 1. The AS100 and AS300 (Fig.1a-b) mainly composed of the crystalline phases of $\mathrm{SiO}_{2}$ and calcite. In contrast, for the AS800 (Fig. 1c), the peak of calcite disappeared due to its decomposition at $800^{\circ} \mathrm{C}$. No peaks corresponded to
TABLE-1

MAIN COMPOSITIONS AND SPECIFIC AREAS OF THE AS100, AS300 AND AS800

\begin{tabular}{cccc} 
Composition & AS100 & AS300 & AS800 \\
\hline $\mathrm{SiO}_{2}($ wt \%) & 46.5 & 48.7 & 51.0 \\
$\mathrm{Al}_{2} \mathrm{O}_{3}($ wt \%) & 22.7 & 24.2 & 26.3 \\
$\mathrm{Fe}_{2} \mathrm{O}_{3}($ wt \%) & 5.31 & 5.70 & 5.35 \\
$\mathrm{CaO}($ wt \%) & 7.71 & 8.31 & 8.29 \\
$\mathrm{MgO}($ wt \%) & 2.33 & 2.36 & 2.49 \\
$\mathrm{TiO}_{2}($ wt \%) & 0.50 & 0.53 & 0.52 \\
$\mathrm{~K}_{2} \mathrm{O}($ wt \%) & 2.07 & 2.18 & 2.17 \\
$\mathrm{Na}_{2} \mathrm{O}($ wt \%) & 0.66 & 0.63 & 0.71 \\
LOI & 10.0 & 5.00 & - \\
$\mathrm{S}_{\text {BET }}\left(\mathrm{m}^{2} / \mathrm{g}\right)$ & 62.6 & 67.1 & 19.5
\end{tabular}

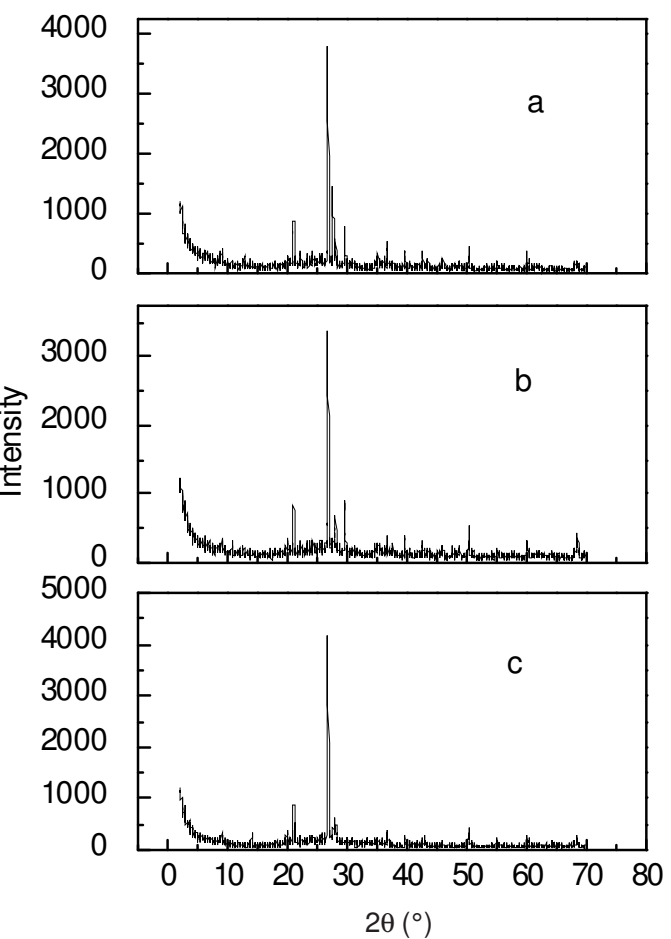

Fig. 1. XRD patterns of three adsorbents: (a) AS100, (b) AS300 and (c) AS800

Al hydr(oxides) in all the three adsorbents were found, which may be due to the fact that the Al hydr(oxides) existed in these samples were amorphous ${ }^{17,19}$.

Fig. 2 shows the FTIR spectra of the AS100, AS300 and AS800. It can be seen from Fig. 2a-b, the spectrum of AS100 was similar to that of AS300, which indicates that the increase of temperature from $100-300{ }^{\circ} \mathrm{C}$ had an apparent effect on their surface properties. For the two adsorbents, the bands at 430 and $470 \mathrm{~cm}^{-1}$ were corresponded to the deformation vibrations of Si-O and $\mathrm{Si}-\mathrm{O}-\mathrm{Si}$, respectively ${ }^{20}$. The band at $530 \mathrm{~cm}^{-1}$ was related to the stretching vibrations of $\mathrm{Si}-\mathrm{O}-\mathrm{Al}^{21}$. The band at $875 \mathrm{~cm}^{-1}$ was resulted from the out-of-plane bending of calcite ${ }^{22}$. The band around $1030 \mathrm{~cm}^{-1}$ represented the Si-O-Si stretching vibration $^{21,23}$. The band at $1440 \mathrm{~cm}^{-1}$ was due to the bending vibration of $\mathrm{CH}_{2}{ }^{24}$. The band around $3620 \mathrm{~cm}^{-1}$ was because of stretching vibrations of Free $\mathrm{OH}^{25}$. The bend at $1660 \mathrm{~cm}^{-1}$ for AS100 was attributed to the nonconjugated stretching vibration of $\mathrm{C}=\mathrm{C}^{25}$, but the same vibration for AS300 was shifted to $1620 \mathrm{~cm}^{-1}$ and the peak was weakened, which was due to the fact that $\pi$ bond in $\mathrm{C}=\mathrm{C}$ was ruptured at $300^{\circ} \mathrm{C}$. 


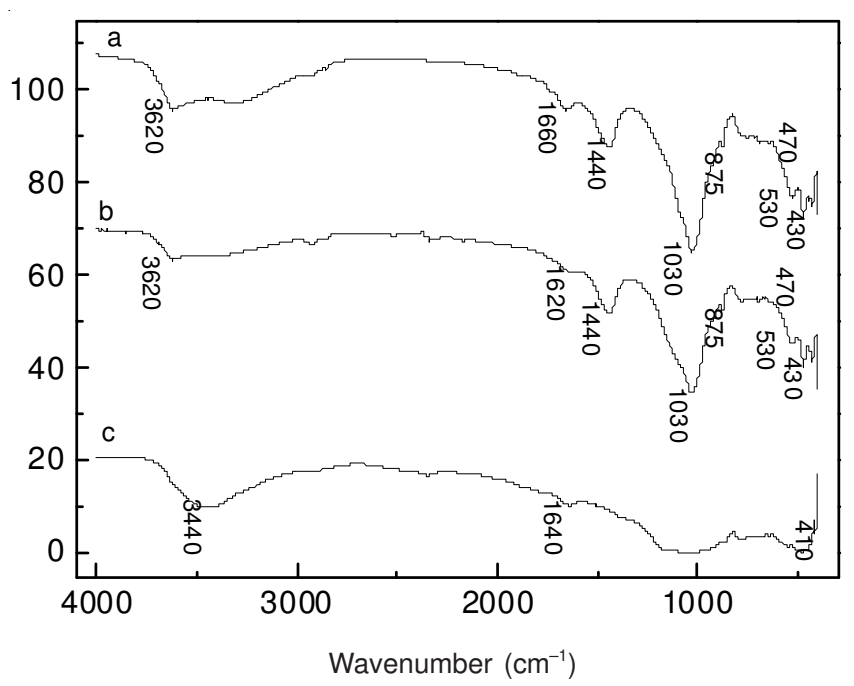

Fig. 2. FT-IR spectra of (a) AS100; (b) AS300; (c) AS800

Compared with the spectra of AS100 and AS300, the spectrum of AS800 deformed greatly, which indicated that the surface property of alum sludge was greatly changed after being calcined at $800{ }^{\circ} \mathrm{C}$. The band at $410 \mathrm{~cm}^{-1}$ was ascribed to the bending vibration of $\mathrm{O}-\mathrm{Si}-\mathrm{O}^{26}$, the peaks at 430,470 , 530 and $857 \mathrm{~cm}^{-1}$ disappeared, indicating the calcite was decomposed at $800^{\circ} \mathrm{C}$, which is consistent with the XRD data. The stretching vibration of $\mathrm{C}=\mathrm{C}$ was shifted to $1640 \mathrm{~cm}^{-1}$ and the peak was shallower. This was also caused by decomposition of alum sludge. The bending vibrations of O-Si-O bonds appeared at $410 \mathrm{~cm}^{-1}$. The broad band at $3440 \mathrm{~cm}^{-1}$ was related to the intermolecular $\mathrm{H}$ bonds ${ }^{24}$.

Effect of heat treatment: Fig. 3 shows the variation of alum sludge adsorption capacity with the change of heat treatment. Heat treatment had a significant impact on the activation of alum sludge. When the temperature was increased from $100-300^{\circ} \mathrm{C}$, the alum sludge adsorption capacity of phosphorus increased from $5.37-8.45 \mathrm{mg} / \mathrm{g}$. The phosphorus removal decreased to $1.99 \mathrm{mg} / \mathrm{g}$ as temperature was increased to 800 ${ }^{\circ} \mathrm{C}$. The alum sludge treated at $300{ }^{\circ} \mathrm{C}$ (AS300) was used to carry out the following experiments.

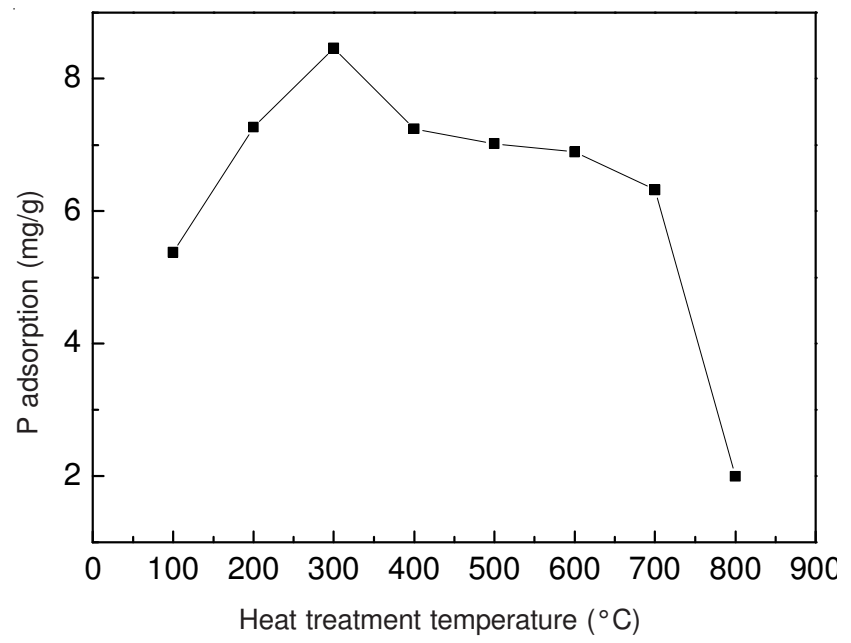

Fig. 3. Effect of heat treatment temperature on the activation of alum sludge $\left(\mathrm{C}_{0}: 40 \mathrm{mg} / \mathrm{L}\right.$, alum sludge dosage: $4 \mathrm{~g} / \mathrm{L}$, temperature: $35^{\circ} \mathrm{C}$, reaction time: $24 \mathrm{~h}$, agitation speed: $120 \mathrm{rpm}, \mathrm{pH}=7$ )
Effect of AS300 dose on removal of phosphorus: The relationship between alum sludge dose and the amount of phosphorus adsorbed on alum sludge is shown in Fig. 4. It can be seen that the amount of adsorbed phosphorus increased with increasing AS300 dose because more AS300 offered more available adsorption sites. The adsorption density, the amount of phosphorus adsorbed on per unit mass of AS300 decreased as the AS300 dose increased, resulting from the fact that the adsorption sites through the adsorption process were unsaturated. Another probable reason for the result was that particle interaction such as aggregation at higher dose of adsorbent could decrease the total surface area of the adsorbent and increase path length of diffusion, leading to lower phosphorus adsorption $^{27}$.

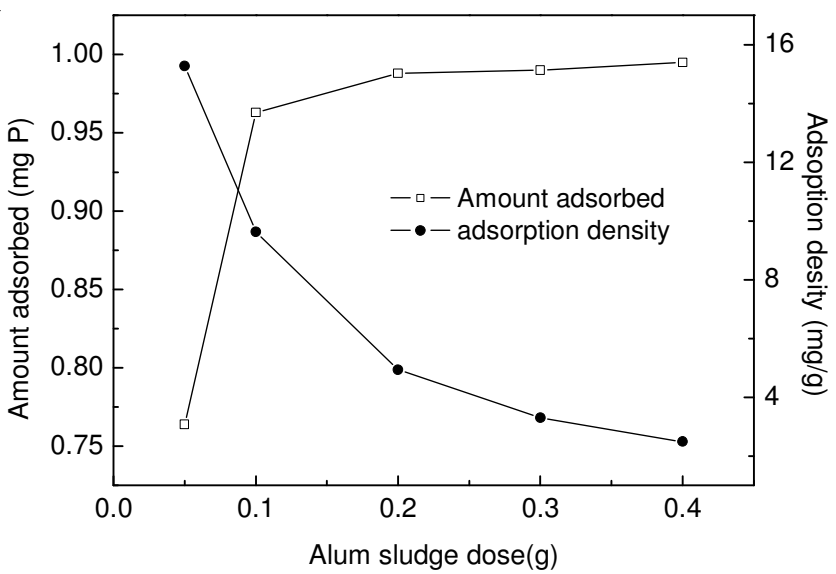

Fig. 4. Effect of AS300 dose onto phosphorus removal $\left(\mathrm{C}_{0}: 40 \mathrm{mg} / \mathrm{L}\right.$, temperature: $35^{\circ} \mathrm{C}$, reaction time: $24 \mathrm{~h}$, agitation speed: $120 \mathrm{rpm}$, $\mathrm{pH}=7$ )

Effect of pH: It is generally believed that the solution $\mathrm{pH}$ plays an important role in adsorption process. Fig. 5 shows the effect of $\mathrm{pH}$ on the adsorption of phosphorus onto AS300. The amount of adsorbed phosphorus decreased from 9.75 to $7.06 \mathrm{mg} / \mathrm{g}$ when the solution $\mathrm{pH}$ increased from 3-9. The results indicate lower $\mathrm{pH}$ was favorable for phosphorus adsorption onto AS300, which is in agreement with the previous results reported by Yang et al. ${ }^{19}$ and by Kim et al..$^{28}$ The $\mathrm{pH}$-dependent phosphorus adsorption onto AS300 can be explained by the following reasons ${ }^{6,17}$. First, phosphorus adsorption was coupled with the release of -OH on the surface of AS300 into solution. Secondly, more $\mathrm{OH}^{-}$in solution competed with phosphorus for the active sites on the surface of AS300 as solution $\mathrm{pH}$ increases. Furthermore, the counter-iron layer formed by the $\mathrm{OH}^{-}$adsorbed on the surface of AS300 weakened the surface affinity of the surface of AS300 to phosphorus. Hence it led to a low phosphorus adsorption. Additionally, the different adsorption reactions took place at different $\mathrm{pH}$ as follows:

$$
\begin{aligned}
& \mathrm{M}-\mathrm{OH}+3 \mathrm{H}^{+}+\mathrm{PO}_{4}{ }^{3-} \rightarrow \mathrm{M}-\mathrm{H}_{2} \mathrm{PO}_{4}+\mathrm{H}_{2} \mathrm{O} \\
& 2 \mathrm{M}-\mathrm{OH}+3 \mathrm{H}^{+}+\mathrm{PO}_{4}{ }^{3-} \rightarrow(\mathrm{M}-)_{2} \mathrm{HPO}_{4}+\mathrm{H}_{2} \mathrm{O} \\
& \mathrm{M}-\mathrm{OH}+\mathrm{H}^{+}+\mathrm{PO}_{4}{ }^{3-} \rightarrow \mathrm{M}-\mathrm{PO}_{4}{ }^{2-}+\mathrm{H}_{2} \mathrm{O} \\
& \mathrm{M}-\mathrm{OH}+2 \mathrm{H}^{+}+\mathrm{PO}_{4}{ }^{3-} \rightarrow \mathrm{M}-\mathrm{HPO}_{4}^{-}+\mathrm{H}_{2} \mathrm{O}
\end{aligned}
$$




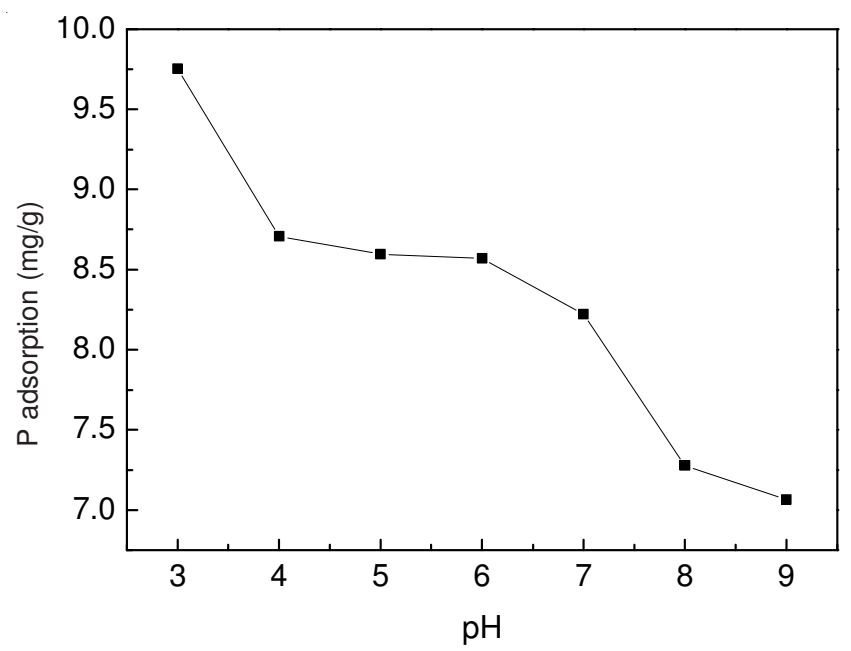

Fig. 5. Effect of $\mathrm{pH}$ on adsorption of phosphorus onto AS300 $\left(\mathrm{C}_{0}: 40 \mathrm{mg}\right)$ $\mathrm{L}$, alum sludge dosage: $4 \mathrm{~g} / \mathrm{L}$, temperature: $35^{\circ} \mathrm{C}$, reaction time: 24 h, agitation speed: $120 \mathrm{rpm}, \mathrm{pH}=7$ )

where $\mathrm{M}-\mathrm{OH}$ represents the surface of AS300. At lower $\mathrm{pH}$, reaction (2) and (3) took place. The products $\mathrm{M}-\mathrm{H}_{2} \mathrm{PO}_{4}$ and $(\mathrm{M}-)_{2} \mathrm{HPO}_{4}$ were electrically neutral and were favorable for the diffusion of phosphorus to the surface of AS300. In contrast, reaction (4) and (5) took place at higher $\mathrm{pH}$ and the negatively charged $\mathrm{M}-\mathrm{PO}_{4}{ }^{2-}$ and $\mathrm{M}-\mathrm{HPO}_{4}{ }^{-}$were produced, which hindered the phosphorus diffusion to the surface of AS300.

Adsorption kinetics: Fig. 6 shows the adsorption of phosphorus onto AS300 at different initial phosphorus concentration. In order to examine the phosphorus adsorption mechanism on the alum sludge sorbents, the adsorption kinetic were investigated using three different kinetic models.

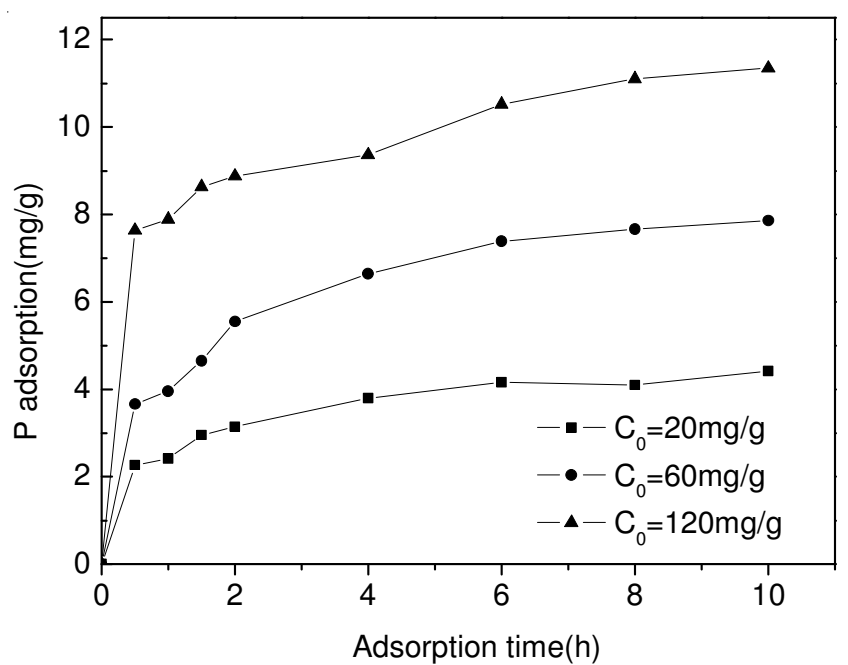

Fig. 6. Adsorption of phosphorus onto AS300 at different initial phosphorus concentration. (AS300 dosage: $4 \mathrm{~g} / \mathrm{L}$, temperature: $35^{\circ} \mathrm{C}$, agitation speed: $120 \mathrm{rpm}, \mathrm{pH}=7$ )
The pseudo first-order equation was used to describe the adsorption and its linear form is as follows ${ }^{29}$ :

$$
\log \left(\mathrm{q}_{\mathrm{e}}-\mathrm{q}_{\mathrm{t}}\right)=\log \mathrm{q}_{\mathrm{e}}-\frac{\mathrm{k}_{1}}{2.303} \mathrm{t}
$$

where $\mathrm{q}_{\mathrm{e}}$ and $\mathrm{q}_{\mathrm{t}}$ are the amount of phosphorus adsorbed on AS300 at equilibrium at time $\mathrm{t}(\mathrm{mg} / \mathrm{g})$, respectively and $\mathrm{k}_{1}$ is the equilibrium rate constant of pseudo first-order equation (1/min).

$\mathrm{q}_{\mathrm{e}}$ and $\mathrm{k}_{1}$ were obtained from the slopes and intercepts of the plots of $\log \left(\mathrm{q}_{\mathrm{e}}-\mathrm{q}_{\mathrm{t}}\right)$ versus $\mathrm{t}$. However, the $\mathrm{q}_{\mathrm{e}}$, measured from experiments for different phosphorus concentrations, 20, 60 and $120 \mathrm{mg} / \mathrm{L}$, are $4.418,7.863$ and $11.35 \mathrm{mg} / \mathrm{g}$, respectively, which deviated considerably from the theoretical data shown in Table- 2 . The correlation coefficients $\mathrm{R}^{2}$ for the firstorder kinetic model obtained at all the three initial concentrations were lower than these of the second-order kinetic model and were higher than two $\mathrm{R}^{2}$ for the Elovich equation at the initial concentrations of 20 and $60 \mathrm{mg} / \mathrm{L}$, but lower than that of the Elovich equation at the initial concentration of $120 \mathrm{mg} / \mathrm{L}$.

The pseudo second-order equation was also used to describe the adsorption process. The linear form of the pseudo secondorder equation is given as follows ${ }^{30}$ :

$$
\frac{\mathrm{t}}{\mathrm{q}_{\mathrm{t}}}=\frac{1}{\mathrm{k}_{2} \mathrm{qe}^{2}}+\frac{\mathrm{t}}{\mathrm{q}_{\mathrm{e}}}
$$

where $\mathrm{k}_{2}$ is the equilibrium rate constant of pseudo secondorder equation $(\mathrm{g} / \mathrm{mg} \mathrm{min})$. The slopes and intercepts of plots of $\mathrm{t} / \mathrm{q}_{\mathrm{t}}$ versus $\mathrm{t}$ were used to determine the second-order rate constant $\mathrm{k}_{2}$. The parameters of the second-order kinetic model were listed in Table-2. It can be seen that the experimental data of $\mathrm{q}_{\mathrm{e}}$ are in good accordance with the theoretical data calculated from the model. The three correlation coefficients $\mathrm{R}^{2}$ for the second-order kinetic model were greater than 0.995 for all the three concentrations.

The linear form of the Elovich equation is expressed as follows ${ }^{31,32}$ :

$$
\mathrm{q}_{\mathrm{t}}=\frac{1}{\beta} \ln (\alpha \beta)+\frac{1}{\beta} \ln \mathrm{t}
$$

where $\alpha$ is the initial sorption rate $(\mathrm{mg} / \mathrm{g} \min )$ and the parameter $\beta$ is related to the extent of surface coverage and activation energy for chemisorption $(\mathrm{g} / \mathrm{mg})^{32}$.

The slopes and intercepts of plots of $\mathrm{q}_{\mathrm{t}}$ versus $\ln \mathrm{t}$ were used to determine the second-order rate constant $\mathrm{k}_{2}$. The correlation coefficients $\mathrm{R}^{2}$ varied from $0.945-0.976$ for all the three reactions, which indicates the Elovich equation was unfit to describe the adsorption system.

Adsorption isotherms: Fig. 7 shows the equilibrium adsorption isotherm of phosphorus onto AS300. It can be seen

\begin{tabular}{|c|c|c|c|c|c|c|c|c|c|}
\hline \multirow{3}{*}{$\begin{array}{l}\text { P initial concentration } \\
(\mathrm{mg} / \mathrm{L})\end{array}$} & \multirow{3}{*}{\multicolumn{2}{|c|}{$\begin{array}{l}\text { KINETIC PARAMETER } \\
\text { Pseudo first-order } \\
\mathrm{K}_{1}(1 / \mathrm{min}) \quad \mathrm{q}_{\mathrm{e}}(\mathrm{mg} / \mathrm{g})\end{array}$}} & \multicolumn{5}{|c|}{$\begin{array}{c}\text { TABLE-2 } \\
\text { THE ADSORPTION OF PHOSPHORIC ONTO AS300 }\end{array}$} & \multirow{2}{*}{\multicolumn{2}{|c|}{ ovich equation }} \\
\hline & & & & Pseudd & econd-order & & & & \\
\hline & & & $\mathrm{R}^{2}$ & $\mathrm{~K}_{2} \mathrm{~g} /(\mathrm{mg} \min )$ & $\mathrm{q}_{\mathrm{e},}(\mathrm{mg} / \mathrm{g})$ & $\mathrm{R}^{2}$ & $\alpha$ & $\beta$ & $\mathrm{R}^{2}$ \\
\hline 20 & 0.006 & 3.107 & 0.983 & 0.489 & 4.773 & 0.998 & 0.372 & 1.263 & 0.976 \\
\hline 60 & 0.065 & 6.069 & 0.990 & 0.010 & 8.666 & 0.997 & 0.422 & 0.639 & 0.970 \\
\hline 120 & 0.006 & 6.436 & 0.923 & 0.021 & 11.72 & 0.995 & 13.68 & 0.790 & 0.945 \\
\hline
\end{tabular}
that the phosphorus adsorbed on per unit mass of AS300 increased with the phosphorus concentration at equilibrium 
TABLE-3

LANGMUIR, FREUNDLICH AND TEMKIN ISOTHERM CONSTANTS FOR P ADSORPTION AT DIFFERENT TEMPERATURES

\begin{tabular}{cccc|ccc|ccc}
\hline \multirow{2}{*}{$\mathrm{T}\left({ }^{\circ} \mathrm{C}\right)$} & \multicolumn{3}{c|}{ Langmuir } & \multicolumn{3}{c}{ Freundlich } & \multicolumn{3}{c}{ Temkin } \\
\cline { 2 - 10 } & $\mathrm{q}_{\max }(\mathrm{mg} / \mathrm{g})$ & $\mathrm{b}$ & $\mathrm{R}^{2}$ & $\mathrm{k}_{\mathrm{f}}(\mathrm{L} / \mathrm{g})$ & $\mathrm{n}$ & $\mathrm{R}^{2}$ & $\mathrm{~B}$ & $\mathrm{~A}(\mathrm{~L} / \mathrm{g})$ & $\mathrm{R}^{2}$ \\
\hline 5 & 12.66 & 0.049 & 0.960 & 2.220 & 3.080 & 0.995 & 13.21 & 0.769 & 0.942 \\
20 & 16.10 & 0.066 & 0.965 & 3.404 & 3.384 & 0.994 & 15.96 & 0.720 & 0.931 \\
35 & 19.08 & 0.081 & 0.967 & 3.980 & 3.192 & 0.995 & 17.87 & 0.700 & 0.920 \\
\hline
\end{tabular}

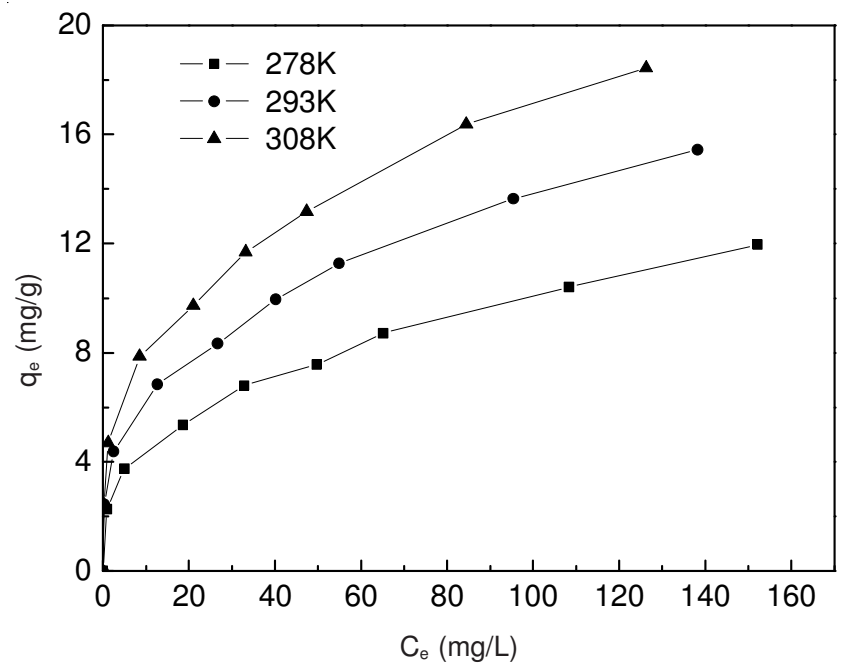

Fig. 7. Isotherm of phosphorus adsorption onto AS300 (AS300 dosage: 4 $\mathrm{g} / \mathrm{L}$, agitation speed: $120 \mathrm{rpm}, \mathrm{pH}=7$, reaction time: $24 \mathrm{~h}$ )

and higher temperature led to better phosphorus adsorption. Adsorption isotherm offers information about how adsorbate reacts with adsorbent surface and is very important for optimizing the use of an adsorbent. So, three isotherm models were adopted to explain the adsorption data obtained from the experiments.

The Langmuir isotherm is widely used to describe the homogeneous sorption where each adsorbate molecule adsorbed onto the surface has equal adsorption activation energy ${ }^{33}$. The linear form of the Langmuir equation is expressed as:

$$
\frac{\mathrm{C}_{\mathrm{e}}}{\mathrm{q}_{\mathrm{e}}}=\frac{1}{\mathrm{bq}_{\max }}+\frac{\mathrm{C}_{\mathrm{e}}}{\mathrm{q}_{\max }}
$$

where $\mathrm{q}_{\mathrm{e}}(\mathrm{mg} / \mathrm{g})$ is the amount of phosphorus adsorbed per unit mass of adsorbent at equilibrium, $\mathrm{C}_{\mathrm{e}}(\mathrm{mg} / \mathrm{L})$ is the phosphorus concentration in solution at equilibrium, $\mathrm{q}_{\max }$ is the theoretical monolayer saturation capacity, $\mathrm{b}$ is the Langmuir equilibrium constants. The values of $\mathrm{q}_{\max }$ and $\mathrm{b}$ were obtained from the slopes and the intercepts of the linear plots of $\mathrm{C}_{\mathrm{e}} / \mathrm{q}_{\mathrm{e}}$ versus $\mathrm{C}_{\mathrm{e}}$. The values of the Langmuir constants , monolayer saturation capacities $\mathrm{q}_{\max }$ and the correlation coefficients $\mathrm{R}^{2}$ are listed in Table-3. The monolayer saturation capacities of AS300 at the three temperatures were 12.66, 16.10 and $19.08 \mathrm{mg} / \mathrm{g}$, respectively. The values of the correlation coefficient were higher than the Temkin isotherm values but lower than those of the Freundlich isotherm.

The Freundlich isotherm is often used for heterogeneous surface energy systems ${ }^{32}$. The linearized form of Freundlich equation is given as:

$$
\log \mathrm{q}_{\mathrm{e}}=\log \mathrm{k}_{\mathrm{f}}+\frac{1}{\mathrm{n}} \log \mathrm{C}_{\mathrm{e}}
$$

where $\mathrm{k}_{\mathrm{f}}$ is the Freundlich constant and is the Freundlich exponent. The values of $\mathrm{n}$ and $\mathrm{k}_{\mathrm{f}}$ were obtained from the slopes and intercepts of the linear plot of $\log \mathrm{q}_{\mathrm{e}}$ versus $\log \mathrm{C}_{\mathrm{e}}$. The values of the Freundlich $\mathrm{k}_{\mathrm{f}}$, the Freundlich exponent $\mathrm{n}$ and the correlation coefficients $\mathrm{R}^{2}$ are listed in Table- 3 . The values of the Freundlich correlation coefficient were the highest one in the three models, which indicated that the Freundlich isotherm equation fitted the experimental data best.

The Temkin isotherm was also used and its linearized form is as follows ${ }^{32}$ :

$$
\mathrm{q}_{\mathrm{e}}=\frac{\mathrm{RT}}{\mathrm{b}} \ln \mathrm{A}+\frac{\mathrm{RT}}{\mathrm{b}} \ln \mathrm{C}_{\mathrm{e}}
$$

where $\mathrm{RT} / \mathrm{b}=\mathrm{B}$. The values of A and B were determined from the intercepts and slopes of the linear plots of $\mathrm{q}_{\mathrm{e}}$ versus $\ln \mathrm{C}_{\mathrm{e}}$. The values of $A$ and $B$ and the correlation coefficients $R^{2}$ are listed in Table-3. The correlation coefficients were lower than the other two isotherm values for all the three cases indicated that the Temkin model did not fitted the experimental data.

Thermodynamic studies: Temperature is one of the key factors that influence the adsorption process. To investigate the effect of temperature, the phosphorus adsorption on AS300 was carried out at three different temperatures 5,20 and $35^{\circ} \mathrm{C}$, respectively. The following three equations were used to calculate the thermodynamic parameters of phosphorus adsorption on $\mathrm{AS} 300^{34}$.

$$
\begin{gathered}
\ln \mathrm{K}_{\mathrm{d}}=\frac{\Delta \mathrm{S}^{\mathrm{o}}}{\mathrm{R}}+\frac{\Delta \mathrm{H}^{\mathrm{o}}}{\mathrm{RT}} \\
\mathrm{K}_{\mathrm{d}}=\frac{\left(\mathrm{C}_{0}-\mathrm{C}_{\mathrm{e}}\right)}{\mathrm{C}_{\mathrm{e}}} \frac{\mathrm{V}}{\mathrm{m}} \\
\Delta \mathrm{G}^{\mathrm{o}}=\Delta \mathrm{H}^{\mathrm{o}}-\mathrm{T} \Delta \mathrm{S}^{\mathrm{o}}
\end{gathered}
$$

where $\mathrm{K}_{\mathrm{d}}$ is the distribution coefficient $(\mathrm{L} / \mathrm{kg}) ; \Delta \mathrm{S}^{\mathrm{o}}$ is the standard entropy change $(\mathrm{KJ} / \mathrm{mol} \mathrm{K}) ; \Delta \mathrm{H}^{\circ}$ is the standard enthalpy change $(\mathrm{KJ} / \mathrm{mol}) ; \mathrm{R}$ is the ideal gas constant $(8.314$ $\mathrm{J}$ mol/K); $\mathrm{T}$ is the reaction temperature $(\mathrm{K}) ; \mathrm{C}_{0}$ and $\mathrm{C}_{\mathrm{e}}$ are the initial and final phosphorus concentrations of in solution ( $\mathrm{mg} /$ $\mathrm{L})$, respectively; $\mathrm{V}$ is the volume of the solution $(\mathrm{mL}) ; \mathrm{m}$ is the mass of the adsorbent; $\Delta \mathrm{G}^{\mathrm{o}}$ is the standard Gibbs free energy change $(\mathrm{KJ} / \mathrm{mol})$.

$\Delta \mathrm{S}^{\mathrm{o}}$ and $\Delta \mathrm{H}^{\circ}$ are obtained from the slopes and intercepts of the plots of $\ln \mathrm{K}_{\mathrm{d}}$ versus $1 / \mathrm{T}, \Delta \mathrm{G}^{\mathrm{o}}$ is calculated from equation. The values of $\Delta \mathrm{S}^{\mathrm{o}}, \Delta \mathrm{H}^{\mathrm{o}}$ and $\Delta \mathrm{G}^{\mathrm{o}}$ are listed in Table-4. It can be seen that the values of $\Delta \mathrm{G}^{\mathrm{o}}$ at the three temperatures were negative, indicating the spontaneous nature of phosphorus adsorption on AS300. The decrease in $\Delta \mathrm{G}^{\mathbf{o}}$ values with the rise of temperature indicates that higher temperature was favourable for phosphorus adsorption because better ion desolvation occurred at higher temperature ${ }^{35}$. The positive $\Delta \mathrm{H}^{\circ}$ values means that the adsorption process was endothermic. 


\begin{tabular}{|c|c|c|c|c|c|}
\hline & $\begin{array}{r}\text { THERMC } \\
\text { FLORII }\end{array}$ & $\begin{array}{l}\text { TABLE-4 } \\
\text { YNAMIC PAR } \\
\text { ADSORPIIOI }\end{array}$ & $\begin{array}{l}\text { METEF } \\
\text { DNTO }\end{array}$ & $\begin{array}{l}\text { FOR } \\
300 \\
\end{array}$ & \\
\hline $\mathrm{C}_{0}$ & $\Delta \mathrm{H}^{\circ}(\mathrm{kJ}$ & $\Delta S^{o}$ & & $\Delta \mathrm{G}^{\mathrm{o}}$ & \\
\hline & $\left.\mathrm{mol}^{-1}\right)$ & $\left(\mathrm{kJ} \mathrm{mol}^{-1} \mathrm{~K}^{-1}\right)$ & $278 \mathrm{~K}$ & $293 \mathrm{~K}$ & $305 \mathrm{~K}$ \\
\hline 10 & 33.72 & 0.19 & -18.42 & -21.24 & -23.49 \\
\hline 20 & 38.45 & 0.19 & -15.29 & -18.19 & -20.51 \\
\hline 40 & 23.46 & 0.13 & -13.43 & -15.42 & -17.01 \\
\hline 60 & 19.04 & 0.11 & -12.33 & -14.02 & -15.37 \\
\hline 80 & 19.93 & 0.11 & -11.64 & -13.34 & -14.71 \\
\hline 100 & 17.40 & 0.10 & -11.35 & -12.91 & -14.15 \\
\hline 150 & 16.71 & 0.10 & -10.56 & -12.04 & -13.21 \\
\hline 200 & 14.71 & 0.09 & -10.12 & -11.46 & -12.53 \\
\hline
\end{tabular}

The positive values of $\Delta \mathrm{S}^{\circ}$ indicate the lower order of reaction during the adsorption of phosphorus onto AS300. The possible reason is that the water molecules adsorbed on the surface of AS300 gained more translational entropy than that lost by the phosphorus when they were displaced by phosphorus, leading to the prevalence of randomness in the system ${ }^{36}$.

\section{Conclusion}

Batch experiments were carried out to investigate the effect of heat treatment on alum sludge adsorption capacity for phosphorus removal. The best phosphorus removal was achieved by the alum sludge treated at $300{ }^{\circ} \mathrm{C}$ (AS300). The phosphorus adsorption from the aqueous solutions onto AS300 depended on adsorbent dosage, initial $\mathrm{pH}$ of the solution, reaction temperature. Lower $\mathrm{pH}$ and higher dosage and temperature were favorable for phosphorus adsorption. The phosphorus adsorption onto the alum sludge adsorbent fitted to Freundlich isotherm very well and the adsorption kinetics followed the pseudo-second-order rate equation. The positive $\Delta \mathrm{G}^{\mathrm{o}}$ and negative $\Delta \mathrm{H}^{\mathrm{o}}$ indicate the spontaneous and endothermic nature of phosphorus adsorption process onto AS300. As a worldwide by-product from the drinking water treatment plant, alum sludge is low cost compared with other adsorbents. Alum sludge has a bright prospect in application for removal of phosphorus from wastewater due to its high adsorption capacity.

\section{ACKNOWLEDGEMENTS}

The authors gratefully acknowledged the financial support from both the starting fund for talents of North China University of water resources and Electric Power and the scientific research key project fund of Education department of Henan province (No. 13B560114). Xiwang Zhang specially thanks for the fellowship provided by Australia Research Council (DP110103533).

\section{REFERENCES}

1. http://jcs.mep.gov.cn/hjzl/zkgb/2011zkgb/201206/t20120606_ 231040.htm

2. Hiroyuki Yoshida and Wilmer A. Galinada, AIChE J., 48, 2193 (2002).

3. M.H. Nejad, A. Takdastan, N. Jaafarzadeh, M.A. Mogadam and N. Mengelizadeh, Asian J. Chem., 25, 2565 (2013).

4. N.O. Yigit and S. Mazlum, Environ. Technol., 28, 83 (2007).

5. C.Y. Wu, Y.Z. Peng, X.L. Li and S.Y. Wang, J. Environ. Eng., 136, 1248 (2010).

6. C.J. Liu, Y.Z. Li, Z.K. Luan, Z.Y. Chen, Z.G. Zhang and Z.P. Jia, J. Environ. Sci., 19, 1166 (2007).

7. W. Huang, S. Wang, Z. Zhu, L. Li, X. Yao, V. Rudolph and F. Haghseresht, J. Hazard. Mater., 158, 35 (2008).

8. Y.Q. Zhao, Q.Y. Yue, Q. Li, X. Xu, Z.L. Yang, X.J. Wang, B.Y. Gao and H. Yu, Chem. Eng. J., 193-194, 161 (2012).

9. J. Pradhan, J. Das, S. Das and R.S. Thakur, J. Colloid Interf. Sci., 204, 169 (1998)

10. Y.Z. Li, C.J. Liu, Z.K. Luan, X.J. Peng, C.L. Zhu, Z.Y. Chen, Z.G. Zhan, J.H. Fan and Z.P. Jia, J. Hazard Mater., 137, 374 (2006).

11. P. Pengthamkeerati, T. Satapanajaru and P. Chularuengoaksorn, Fuel, 87, 2469 (2008).

12. S.G. Lu, S.Q. Bai, L. Zhu and H.D. Shan, J. Hazard. Mater., 161, 95 (2009).

13. B. Kostura, H. Kulveitová and J. Lesko, Water Res., 39, 1795 (2005).

14. B.K. Biswas, K. Inoue, K.N. Ghimire, S. Ohta, H. Harada, K. Ohto and H. Kawakita, J. Colloid Interf. Sci., 312, 214 (2007).

15. Q.H. Wang and J.L. He, China Water Wastewater, 18, 65 (2002) in Chinese.

16. M.M. Mortula and G.A. Gagnon, Aquacult. Eng., 36, 193 (2007).

17. Y. Yang, Y.Q. Zhao, A.O. Babatunde, L. Wang, Y.X. Ren and Y. Han, Sep. Purif. Technol., 51, 233 (2006).

18. State Environmental Protection Administration of China, Monitoring and Analysis Methods of Water and Wastewater, China Environmental Science Press, Beijing, edn. 4, p. 246 (2002).

19. D. Tomlinson, S. Kennedy and Y.Q. Zhao, Water Sci. Technol., 54, 207 (2006).

20. M. Ritz, L. Vaculíková and E. Plevová, Acta Geodyn. Geomater, 8, 47 (2011).

21. C. Manoharan, R. Venkatachalapathy, S. Dhanapandian and K. Deenadayalan, Indian J. Pure Appl. Phys., 45, 860 (2007).

22. G.T. Zhou, C.Y. Jimmy, X.C. Wang and L.Z. Zhang, New J. Chem., 28, 1027 (2004).

23. A. Chaisena and K. Rangsriwatananon, Suran. J. Sci. Technol., 11, 289 (2004)

24. I. Uslu, H. Çelikkan, O. Atakol and M.L. Aksu, Hacettepe J. Biol. Chem., 36, 117 (2008).

25. http://infrared.als.lbl.gov/content/web-links/60-ir-band-positions

26. R. Peña-Alonso, L. Téllez, A. Tamayo, F. Rubio, J. Rubio and J.L. Oteo, J. Eur. Ceram. Soc., 27, 969 (2007).

27. A. Shukla, Y.H. Zhang, P. Dubey, J.L. Margrave and S.S. Shukla, J. Hazard. Mater., 95, 137 (2002).

28. J.G. Kim, J.H. Kim, H. Moon, C. Chon and J.S. Ahn, Chem. Spec. Bioavailab., 14, 67 (2003).

29. N. Chen, Z.Y. Zhang, C.P. Feng, M. Li, D.R. Zhu, R.Z. Chen and Norio Sugiura, J. Hazard. Mater., 183, 460 (2010).

30. W. Ma, F.Q. Ya, M. Han and R. Wang, J. Hazard Mater., 143, 296 (2007).

31. C.W. Cheung, J.F. Porter and G. McKay, Water Res., 35, 605 (2001).

32. A. Ornek, M. Ozacar and I.A. Sengil, Biochem. Eng. J., 37, 192 (2007).

33. X.T. Xu, Q. Li, H. Cui, J.F. Pang, L. Sun, H. An and J.P. Zhai, Desalination, 272, 233 (2011).

34. L. Chen and X. Gao, Appl. Radiat. Isotopes, 67, 1 (2009).

35. C.L. Chen and X.K. Wang, Ind. Eng. Chem. Res., 45, 9144 (2006).

36. M. Doula, A. Ioannou and A. Dimirkou, Adsorption, 6, 325 (2000). 